\title{
STUDY ON PROBLEMS IN GELLF́ S TEST
}

By

T. MORI

\section{From the Department of Oto-Rhino-Laryngology Okayama University Medical School (Director: Prof. S. Takahara)}

When the cases of otosclerosis, chronic adhesive otitis media and dislocation of the incudosta pedial joint are examined using conventional Gelle's test, the results are always negative, and the test is of no use for the differential diagnosis of these diseases. Therefore, for the purpose of differential diagnosis, first, being confirmed that Gellé's test by bone conduction was negative, the qualitative test by air conduction was a pneumophon with applied to these cases. The following results were obtained:

1. Otosclerosis: The application of positive or negative pressure to the external auditory canal generally reduces the loudness of air-conducted tones.

2. Otitis media chronica adhesiva: When a negative pressure is applied to the external auditory canal, air-conducted tone decreases in loudness like in the case of otosclerosis but the application of positive pressure to the auditory canal causes no decrease in the loudness of airconducted tone.

3. Dislocation of the incudostapedial joint: When the negative pressure up to $-10 \mathrm{mmHg}$ is applied to external auditory canal air-conducted tone increases in loudness, but when the negative pressure up to $-30 \sim-40 \mathrm{mmHg}$ is applied, the air-conducted tone decreases in loudness. The application of positive pressure causes a decrease in the loudness of air-conducted tone just as in the case of otosclerosis.

Summarizing the above, it seems that the differential diagnosis of those diseases negative to Gelle's test is made to some extent with the use of the qualitative test by air conduction with a pneumophon.

\section{Gellé 氏 法についての 検 討}

外耳道に負荷した陰陽圧の変動に伴う気・骨導 聴力の推移を研究

岡山大学医学部耳悬胝喉科教室（主任：高原浚夫教授）

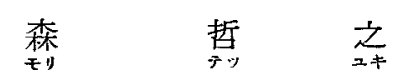

目次

1 緒言

1 検查裝置並びに検查方法

、III検查対象耳並びにその圧変動に件う聴力変化の 成維

1. 正常耳について

a. 量的梌查 b. 貿的検查

2. 神経性蜼㯖耳について
a. 量的梭查
b. 賀的検查

3. 故膜瘾着症耳について
a. 量的榆查
b. 質的検查 
4. 耳硬化起耳について
a. 量的梭查
b. 留的梌查
c. 検查成綪と手衏時所見

5. 砧鐙関简遊離の1泟例について

a. 量的榆盆

b. 筫的检查

$N$ 検查成綪の陰陽性分類

$V$ 総括並びに考按

V 結語

参考交献

\section{I. 緒言}

耳硬化症の診断活の一つとして古くから知られている Gellé 氏法は，耳硬化症以外Dある種の中耳伝音系聅患 に対しても，耳硬化症と同様な䄼查成績を示す事がある ので, 耳硬化症に特有な検查法とは云えない憾がある. そこで私は先づ従来から行われている Gellé 氏法を再 検討し，これを補足充実させることによつて，耳硬化症 に対する本法の診断的価值を向上させたいと念願してこ の研究を企てた。

1881 年 Gellé は London における 国際医学会で, 外耳道に压を垻荷すると，聴力に変化をきたす事を報告 している. 即ち彼の検查法はポリチェル球を短いコム管 によつて外耳道に当てがい，球上あるいは管上に振動す る C 音㕚を置いて気導音を聴かせ，次にポリチェル球 の圧迫によつて外耳道に陽圧を負荷し，音が減弱あるい は消失する事を確認し、これを Gellé 陽性としている。 又その音叉を頭頂部するいは乳突部に置いて骨導音を聴 かせる時も同様つ效果がある事を認めたしかしある種 の中耳伝音系つ難聴耳で王を高める事によつて気導音 は弱くなつたり消失するが，骨導音はその影望を受けな い場合のある事が明らかとなりこれを Gellé 陰性と し，このような検查成續を示するのには鐙骨強直がある と述べている・しかし以上の検查法にはかなり粗雑な点 があるので，私はより正確な検查法にするため，音㕚の 代りに殡正されたオージォメータ一を使用し，外耳道に は陽纴の外に陰珐をむ負荷し，この圧を政密に測定でき るように土夫した。な物気導検查に際して Dishoeck (1938)のブノイモホンを使用した・最初 Dishoeck は 最良聴才带の 测定にこのブノィモホンを使用している ダ,彼は論文の中で将来プ，ィモホンを使用して，Gellé 氏法を行つたら鐙骨強直の決定はより確実になるだろら と予言している.
最近 Zöllner と Thullen はブノイモホンを使用し， 音叉の代りにォージォメーターをを用い，陽仕及び陰圧に よる Gellé 氏改良法を発表して，中耳伝音系の検查法 確立を図つているなな外耳道に陽圧を加える Gellé 氏法に対して陰王を負荷させることを最初に提案した人 は Bartsch (1885) である.

文本邦では 1951 年恩地が耳栓骨導検査法を発表し, 正常耳及び内耳性難聴耳では耳栓择入によつて骨尊音が 堌大するが（この増大は 250 及び $800 \mathrm{cps}$ で最る著明に おきる)，中耳伝音系難聴耳ではこの骨導音増大㤌諗め られないから，この方法は鼓膜に变化がない場合には， 耳小骨連鎖・卵円空の機能障碍を鋭敏に検出する長所が あると紹介している。

しかし前者つ Zöllner と Thullen による Gellé 氏 改良法や後者の恩地氏法によつても，鼓膜に欠損を伴え ないで正常な耳管通気度るもつ中耳伝音系疾患耳，例光 は鼓膜癒着症耳，耳硬化症耳並びに砧鐙関節遊離耳等の 鑑別が可能になつたと云う詳細な報告をみない.とこで 私は内耳開空術を刘象とする耳硬化症を夫等中耳伝音采 諸突患から爁別したい目的のもとに，幾多の先人の業禎 を種々検討した上で，次に述べるような検查装置並びに 検查方法により，これ等諸疾患を㭘查すると共に，所期 の目的に添いしかる簡便に検查しらる方法（新 Gellé 氏法と仮称す）を考案したので，それをこっに報告し諸 氏の御批判を乞う次第である。

\section{II. 検查装置並びに検查方法}

検查は岡大医学部耳悬咽喉科教室内の 防音室で 行つ た。

Maico 製 MAI ォージオメーターを使用し, 気尊㯖 カの测定には Dishoeck の記載に可及的に忠害なブノ イモホンを用いた。そのレシーバーはラシャ及びフェル トで被い，音が外部に透逸するのを防き，約 $4 \mathrm{~cm}$ の誘 導管で外耳に洼するようにした。そして誘導管の端には エボナイト製の有效耳桎を附け，その外側にゴムを当て がい外耳道入口部に対し気密にし，頭蓋骨への骨尊をで きるだけ少くするようにした。その誘導管の中央部に枝 をつけ，マノメーター及び压变動装置（100cc 这射簓を 利用す）を装備した（第1図）。

骨尊㯖力の測定に当つては Maico 製 MAI オーシ ホメーターーに附属している骨導レシーバー及びノィズ・ マスキングを用いた・ 又䑁導聴力湘定の際圧の変動を耳 へ導く装置としては，先のプノイモホンをォージオメー ターから切り離したすのを用いた。 
第 1 図 Pneumophon

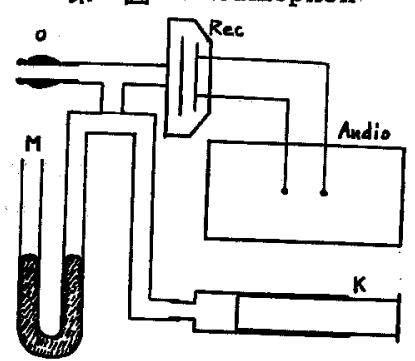

図說明：O：耳栓

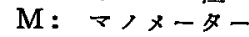

Rec: レシーバー

Audio: オージオメーターー

$\mathrm{K}$ ：圧变動裝置

第1表 オージオメーターの最大出力

\begin{tabular}{|c|c|c|}
\hline 同沸憵 & 氛等の最大出力 & 骨算口最大出力 \\
\hline 125 & 50 & 45 \\
\hline 250 & 65 & 50 \\
\hline 500 & 90 & 50 \\
\hline 750 & 85 & 70 \\
\hline 1000 & 85 & 70 \\
\hline 2000 & 70 & 70 \\
\hline $\begin{array}{l}4000 \\
8000\end{array}$ & 45 & 50 \\
\hline
\end{tabular}

次に気導・骨導聴力を測定する際のオージオメーター の最大出力は第 1 表の如くである.

検查方洗としては気導・骨導共に先つ量的検查を行 い, 次に質的検查を施行した。

双て量的検查では $125,250,500,750,1000,2000$ ， $4000,8000 \mathrm{cps}$ の 8 周波数で気導最小可聴闦值を求め， 次にこの全周波数について夫之 $-20,-40,-60,+20$ ， $+40,+60 \mathrm{mmHg}$ の暊序で圧を負荷して気導閥值を測 定した：文骨尊の最小可聴關值は $8000 \mathrm{cps}$ を除く前記 全周没数で湘定し，更に前記気圧下において骨尊闇值を 求めた・これ等の䦪值決定に当つては所謂上行法によ り，3回以上にわたつて同一の測定を䄼返し，その最小 の值を以つて測定值とした。

次に質的㭘查は 250, 500,750, 1000,2000，4000cps の6 周波数で気尊・骨尊最小可聴閥值上 $5 \mathrm{db}$ の音を被 検耳に聴かせ，大体 2 秒間に $10 \mathrm{mmHg}$ の割合で徐々 に圧を变動させ，先つその音が変化する点，多くは減弱 する点を患者䅉答させ，更に圧の負荷によつて音が消 失する点を指摘させ, 夫ょの圧值をマノメーターで読ん

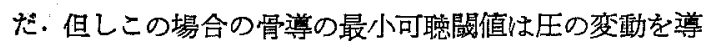
く有孔耳栓を被検耳に装備した場合の閔值を以ってし た.

以上両㭘查共に先つ陰圧で各周波数について検查し，
次に陽圧で祫查した。この煬合仕の変動は最大 \pm 80 $\mathrm{mmHg}$ までとした。即ちこれ以上の気圧下では患者は 極度の鼓膜圧迫乃至疼痛のため不安に媏われるからであ。 る.

なおこれ等の諸検查を行らには極めて長特間を要する。 ため，患者の疲労現象を考慮して大体20 万位の検査で 一応検查を中断し，充分な休息時間を置いて疲労による。 影響を極力避けるように努めた・文患者の一般状態は心 身共に安静な時期を選えだ.

以上の検查方法により正常耳, 神経性難德耳並びに鼓 膜に久損を伴わないで正常な耳管通気度をるつ中耳伝音 禾疾患耳を検查した。

III. 検查対象耳並びにその圧変動に 伴う聴力变化の成樍

1. 正常耳について

耳鏡所見及び耳管通気度に異常なく，鼻・咽頭に疾患 を認めず，既往歴にもなんら耳疾患のない正常聴力をも。 つ10耳を検查対象とした。

a. 量的検查

個々の症例の量的検查成績表は省略し，この成績表よ り正変動に伴う聴力の低下度を算出した (第 2 表).

この表から気導・骨導共に次のような事が明らかにな つた・

i）陰陽孰れの圧によつても，全周波数で大なり小な り聴力の低下をみた・しかしながら $1000 \mathrm{cps}$ 上下の周、 波数域々 $2000 \mathrm{cps}$ 以上の周波数域では，压变動に伴う 聴力低下度の趣は全く異り，前者の聴力低下著明なるに

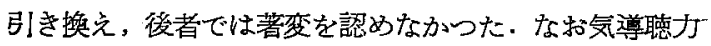
の低下度が特に著明な周波数は $125 ， 250,500 \mathrm{cps}$ であ つた. 即ち $20 \mathrm{mmHg}$ の圧で大多数の症例が $10 \mathrm{db} の$ 聴力低下をみ， $40 \mathrm{mmHg}$ では $15 \mathrm{db}, 60 \mathrm{mmHg}$ では $20 \mathrm{db}$ 以上の聴力低下をみた。又骨導聴力は 125,250 , $500,750 \mathrm{cps}$ 共に同程度の著明な 低下度を示し, 過半 数の症例では $20 \mathrm{mmHg}$ は $10 \mathrm{db}, 40 \mathrm{mmHg}$ は $15 \mathrm{db}$ ， $60 \mathrm{mmHg}$ は $20 \mathrm{db}$ 以上の德力低下をみだ

ii） $20,40,60 \mathrm{mmHg}$ の㓌生に上る聴力低下度之夫. 々に対応する陽压による聴力低下度は大凡等しからた。

iii） $1000 \mathrm{cps}$ 以下の周波数域で自0至 $20 \mathrm{mmHg}$, 自 20 至 $40 \mathrm{mmHg}$, 自 40 至 $60 \mathrm{mmHg}$ の3 種の圧急荷 飞伴う聴力の低下浘を比較すると, 多くの症例で自 0 至 $20 \mathrm{mmHg}$ の圧負荷に上る聴力低下度が最も大きく, 次 K自 20 至 $40 \mathrm{~mm}$ ㄴg, 次伯自 40 至 $60 \mathrm{mmHg}$ の順に低 下度は減少した。

附 耳栓骨導差 
第 2 表 正常耳の量的検查での聴力低下度

(峃姑 d

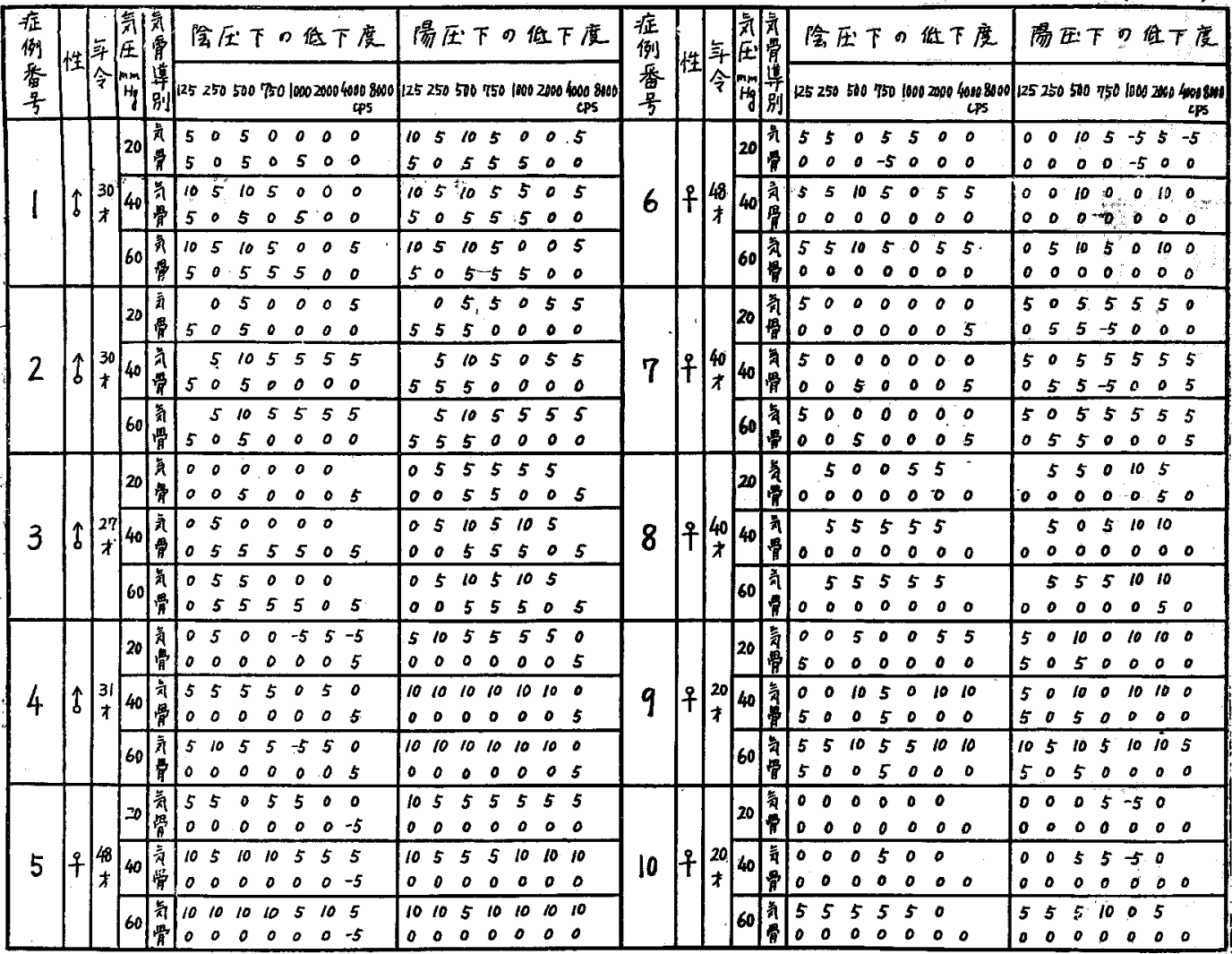

骨導検查で被検耳に取の変動を導く有孔耳栓を装備し ない場合の最小可聴䦪值とこの王変動用の有孔耳烃を施 した場合のそれとの差（便宜的 に耳栓骨尊差之称す）を各症例 別に揚げた（第3表）。これに よると有孔耳栓を被検耳に装備 すると, 総ての症例で聴力上昇 をみた．特に $1000 \mathrm{cps}$ 以下の周 没数域では $2000 \mathrm{cps}$ 以上のそれ より聴力上昇は著明で， $500 \mathrm{cps}$ 次で 250，750cps 恃症例の過 半数で $10 \mathrm{db}$ 以上の恥力上昇を みた・即ち耳栓骨導羑は 10db 以上であつた。

な拉症例で恩地氏法を行つ たが 250, 750cps (Maico 慗 MAI オージオメーターには

第 3 表 正常耳.の耳 栓骨煖差

\begin{tabular}{|c|c|}
\hline 症善 & 1252505000750 1000 20000000 \\
\hline 1 & $\begin{array}{lllllll}5 & 10 & 10 & 10 & 5 & 0 & 0\end{array}$ \\
\hline 2 & $\begin{array}{lllllll}5 & 10 & 10 & 10 & 5 & 0 & 5\end{array}$ \\
\hline 3 & $\begin{array}{lllllll}5 & 15 & 10 & 10 & 10 & 5 & 5\end{array}$ \\
\hline 4 & 101010105550 \\
\hline 5 & $10 \quad 15 \quad 151510 \quad 5 \quad 5$ \\
\hline 6 & 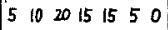 \\
\hline 7 & 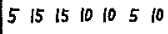 \\
\hline 8 & $\begin{array}{lllllll}5 & 10 & 1055 & 0 & 0\end{array}$ \\
\hline 9 & $\begin{array}{lllllll}5 & 10 & 10 & 10 & 10 & 0 & 0\end{array}$ \\
\hline 10 & 5101510555 \\
\hline
\end{tabular}

(俩位 800cps がないため，750cps で検査を行つた）共に骨 導音増大は $15 \mathrm{db}$ 以上であつた。

\section{b. 質的検查}

第 4 表から気導・胃導共に次のような事が明らかにな つた・

i）陰楊敦れの圧によつても $1000 \mathrm{cps}$ 以下の音はそ の感覚に減弱, 消失をきたした・な挌各周波数別に全症 例を通でて最高の生值を示すと，陰晹孰れの圧でも250, $500 \mathrm{eps}$ で減弱任值 $10 \mathrm{mmHg}$, 消失圧值 $20 \mathrm{mmHg}$ を 示し, 750eps では減弱压值 $16 \mathrm{mmHg}$, 消失圧值 30 $\mathrm{mmHg}$ を示し, $1000 \mathrm{cps}$ では減弱任值 $20 \mathrm{mmHg}$, 消 失圧值 $40 \mathrm{mmHg}$ であつた. 即ち $1000 \mathrm{cps}$ 以下の音は 少くとす $20 \mathrm{mmHg}$ 及び $40 \mathrm{mmHg}$ で夫ね減弱及び消 失をみた・しかし 2000, 4000 cps では $\pm 80 \mathrm{mmHg}$ の 生負荷でる音の減弱あるい消失をみなかつた症例があ つた・第 4 表ではこのよらなるのを×で表した。

ii）音の減弱，消失を起陰压便之陽圧值比較する 
第 4 表 正常耳の鱼的検查成緛 (単位 $\mathrm{mmHg}$ )

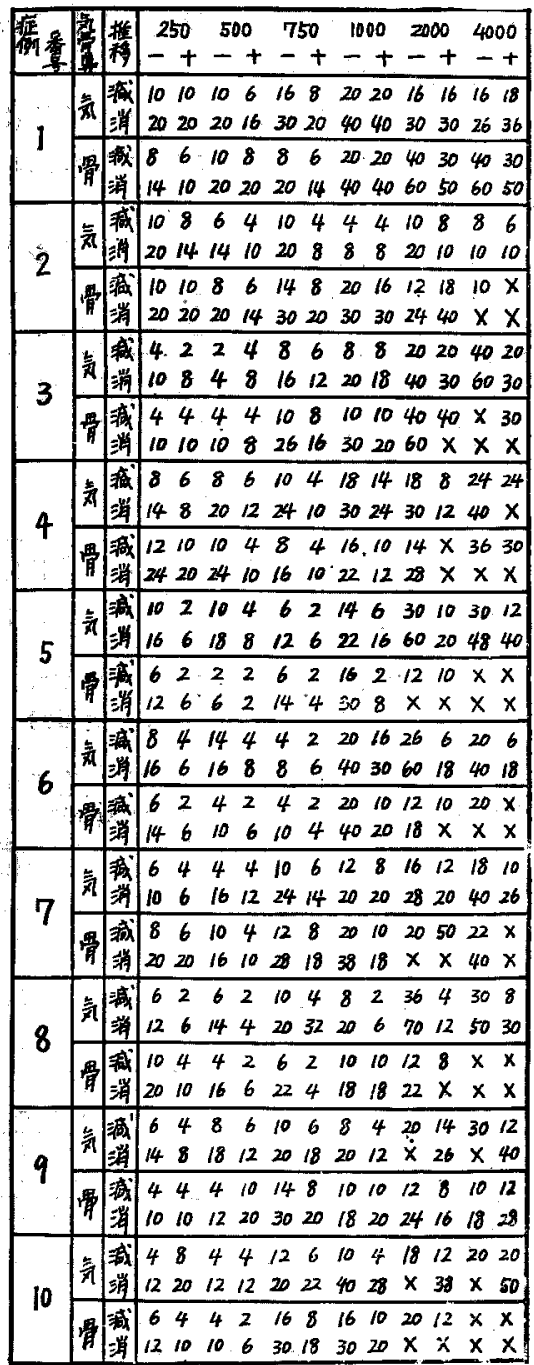

そ，陰圧は陽圷よりも大きな区負荷によつて同一程度の 音の淢鸧消失をきたした。

iii）ある一つの音の減弱圧值と消失圧值を比較する 之, 前者は後者の大凡半分·值であつた。

2. 神経性難聴耳について

耳鏡所見及び耳管通気度に異常なく，鼻・㸶頭にも疾 患を認めないが，既往歴に中毒性難聴の原因と思われる ஆのぶあるか,あるいはこのよらな既往歴はなくてる気 導・骶導聴力検查等から神経性難聴と診断された 5 耳を 検查詨象とした。

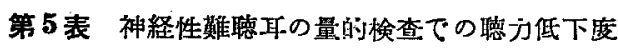

(半 at db)

\begin{tabular}{|c|c|c|c|c|c|c|c|}
\hline \multirow{2}{*}{$\begin{array}{l}\text { 应 } \\
\text { 峢 } \\
\text { 番 } \\
\text { 号 }\end{array}$} & \multirow{2}{*}{\multicolumn{2}{|c|}{ 性 }} & \multirow{2}{*}{ 年 } & \multirow{2}{*}{ 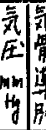 } & \multicolumn{2}{|r|}{ 狯压下の你下度 } & 陽压下の任下哾 \\
\hline & & & & & & $\begin{array}{r}250590 \% 501000200040058000 \\
\text { CPs }\end{array}$ & $\begin{array}{r}1252505027501000200040008500 \\
C P 5\end{array}$ \\
\hline \multirow{3}{*}{1} & \multirow{3}{*}{\multicolumn{2}{|c|}{ q }} & & & & $\begin{array}{cccccccc}5 & 10 & 10 & 5 & 5 & 0 & 5 & 0 \\
5 & 10 & 15 & .10 & 15 & 5 & 0 & \end{array}$ & {$\left[\begin{array}{cccccccc}5 & 10 & 10 & 5 & 5 & 0 & 0 & 0 \\
10 & 5 & 10 & 5 & 10 & 5 & 0 & \end{array} \mid\right.$} \\
\hline & & & & 100 & & $\begin{array}{cccccccc}0 & 15 & 15 & 10 & 10 & 0 & 10 & 5 \\
10 & 15 & 20 & 15 & 20 & 5 & 0\end{array}$ & $\begin{array}{|cccccccc|}5 & 15 & 10 & 10 & 10 & 0 & 5 & 0 \\
15 & 10 & 20 & 10 & 15 & 5 & 0 & \end{array} \mid$ \\
\hline & & & & & & $\begin{array}{llllllll}15 & 20 & 20 & 20 & 20 & 0 & 10 & 5 \\
15 & 20 & 25 & 20 & 25 & 5 & 0\end{array}$ & {$\left[\begin{array}{cccccccc}10 & 15 & 15 & 15 & 15 & 0 & 5 & 5 \\
20 & 15 & 25 & 15 & 20 & 5 & 0 & \end{array} \mid\right.$} \\
\hline \multirow{3}{*}{2} & & & \multirow{3}{*}{$\begin{array}{l}21 \\
t\end{array}$} & & & $\begin{array}{ccccccc}10 & 10 & 10 & 10 & 10 & 0 & 0 \\
10 & 10 & 10 & 5 & 5 & 0 & 10\end{array}$ & $\begin{array}{ccccccc}10 & 10 & 10 & 10 & 10 & 0 & 5 \\
10 & 10 & 10 & 5 & 5 & 5 & 10 \\
\end{array}$ \\
\hline & & 9 & & 40 & & $\begin{array}{ccccccc}5 & 15 & 15 & 15 & 15 & 0 & 5 \\
10 & 15 & 15 & 10 & 10 & 5 & 15\end{array}$ & \begin{tabular}{|lllllll}
15 & 15 & 15 & 15 & 15 & 0 & 10 \\
15 & 10 & 15 & 10 & 10 & 5 & 15
\end{tabular} \\
\hline & & & & & & $\begin{array}{lllllll}20 & 20 & 20 & 20 & 20 & 0 & 10 \\
15 & 20 & 20 & 15 & 15 & 5 & 20\end{array}$ & $\begin{array}{lllllll}20 & 20 & 20 & 20 & 20 & 0 & 10 \\
20 & 15 & 20 & 15 & 15 & 0 & 20\end{array}$ \\
\hline \multirow{3}{*}{3} & & \multirow{3}{*}{$\begin{array}{l}32 \\
\hbar\end{array}$} & $20 \int^{x}$ & & $\begin{array}{llllll}0 & 10 & 10 & 10 & 10 & 0 \\
10 & 5 & 10 & 5 & 5 & 0 \\
0\end{array}$ & $\begin{array}{|llllll|}10 & 5 & 10 & 10 & 5 & 5 \\
5 & 5 & 10 & 5 & 5 & 0 \\
\end{array}$ \\
\hline & & 9 & & & & $\begin{array}{llllll}20 & 15 & 15 & 15 & 10 & 5 \\
15 & 10 & 15 & 20 & 5 & 5 \\
\end{array}$ & $\begin{array}{llllll}15 & 15 & 20 & 15 & 10 & 5 \\
10 & 10 & 15 & 15 & 10 & 0 \\
\end{array}$ \\
\hline & & & & 60 & & $\begin{array}{llllll}25 & 20 & 25 & 20 & 15 & 5 \\
20 & 15 & 25 & 25 & 10 & 5\end{array}$ & $\begin{array}{llllll}20 & 20 & 25 & 20 & 10 & 5 \\
15 & 15 & 20 & 20 & 10 & 5\end{array}$ \\
\hline \multirow{3}{*}{\multicolumn{2}{|c|}{4.}} & & \multirow{3}{*}{32} & ${ }^{20}$ 骨 & & \begin{tabular}{|llllll}
5 & 10 & 10 & 5 & 5 & 0 \\
5 & 10 & 10 & 15 & 5 & 0 \\
\end{tabular} & $\begin{array}{|cccccc|}10 & 10 & 10 & 5 & 10 & 5 \\
5 & 10 & 10 & 10 & 5 & 0 \\
\end{array}$ \\
\hline & & & & 100 & & $\begin{array}{llllll}5 & 20 & 20 & 15 & 15 & 10 \\
0 & 15 & 15 & 20 & 10 & 0 \\
\end{array}$ & $\begin{array}{llllll}15 & 15 & 20 & 15 & 15 & 10 \\
10 & 15 & 15 & 15 & 10 & 5 \\
\end{array}$ \\
\hline & & & & 量 & & $\begin{array}{llllll}20 & 25 & 25 & 20 & 15 & 10 \\
5 & 20 & 20 & 25 & 15 & 5 \\
\end{array}$ & $\begin{array}{llllll}20 & 20 & 25 & 20 & 20 & 10 \\
15 & 20 & 15 & 20 & 15 & 5\end{array}$ \\
\hline \multirow{3}{*}{5} & & \multirow{3}{*}{ 우 } & \multirow{3}{*}{$\begin{array}{l}16 \\
t\end{array}$} & 10 & & $\begin{array}{ccccccc}5 & 5 & 10 & 10 & 5 & 0 & 0 \\
5 & 5 & 10 & 5 & 10 & 0 & 10\end{array}$ & $\begin{array}{lllllll}5 & 5 & 15 & 10 & 5 & 0 & 5 \\
0 & 0 & 5 & 5 & 5 & 5 & 5\end{array}$ \\
\hline & - & & & 10 & & $\begin{array}{lllllll}10 & 10 & 20 & 20 & 15 & 10 & 10 \\
0 & 10 & 15 & 10 & 15 & 0 & 10\end{array}$ & $\begin{array}{lllllll}10 & 10 & 20 & 15 & 10 & 0 & 5 \\
5 & 10 & 10 & 10 & 10 & 0 & 5\end{array}$ \\
\hline & & & & & & $\begin{array}{lllllll}5 & 15 & 25 & 25 & 20 & 10 & 10 \\
5 & 15 & 20 & 15 & 20 & 0 & 15\end{array}$ & $\begin{array}{lllllll}15 & 15 & 30 & 25 & 15 & 5 & 10 \\
15 & 15 & 20 & 10 & 15 & 5 & 10\end{array}$ \\
\hline
\end{tabular}

a. 量的椧查

個々の症例の量的䄼查成績から区变動に伴ら聴力の低 下度を求めた（第５表）、これから気導・骨導共に次の よらな事が明らかになつた。

i）陰陽敦れの压によつても，全周没数で犬なり小な り聴力の低下をみた。しかしながら $1000 \mathrm{cps}$ 以下の問 波数域之 $2000 \mathrm{cps}$ 以上の周波数域では，圧変動に伴う 聴力低下度は全くその趣を異にし，前者では聴力低下著 明なるにも拘らず，後者ではさしたる著変を認めなか つた、特に聴力低下が著しい周洨数は $500 \mathrm{cps}$ で， 20 $\mathrm{mmHg}$ の圧で $10 \mathrm{db}$ の聴力低下をみ， 40, 60 $\mathrm{mmHg}$ では夫ぬ 15，20db 以上の聴力低下をみた。これと大凡 等しい低下度をみた周波数は 250,750 os であつた。

ii) $20,40,60 \mathrm{mmHg}$ の陰圧による聴力低下度と夫 々に奶応する陽任による聴力低下度は大凡等しかつた．

iii）自0至 $20 \mathrm{mmHg}$, 自 20 至 $40 \mathrm{~mm} \mathrm{Hg}$, 自 40 至 
$60 \mathrm{mmHg}$ の3 棟の圧負荷に伴う聴力の低下を比較する 之, $1000 \mathrm{cps}$ 以下の周没数域では自 0 至 $20 \mathrm{mmHg}$ の 圧顀荷による聴力低下度が最も犬きく，次に自 20 至 40 $\mathrm{mmHg}$ ，次に自 40 至 $60 \mathrm{mmHg}$ の順に低下度は減少し た。

\section{附 耳桎骨繶差}

第6表のような成績をえた・これによると有孔耳栓を 被検耳に装㛚した場合，総ての 症例で聴力上贸をみた・特に $1000 \approx p s$ 以下の 周波数域では 2000 sps 以上のそれより聴力上 舁は著明で，殊に $250,500 \mathrm{cps}$ は全症例で耳栓骨導差は $10 \mathrm{db}$ 以上であつた。

な和全症例で恩地氏法を行つ たが， 250,750cps 共に $15 \mathrm{db}$ 以上の骨導音増大をみた。

\section{b. 質的検查}

第 7 表から気導骨導共に次のような事が明らかになつ た。

i）䧔啺敦れの圧によつても，総ての音はその感覚に 減弱, 消失をさたした。なお各周波数で最高の減弱仕值 及び消失圧值を示せば，250，500aps では夫ょ $10 \mathrm{mmHg}$ 及び $20 \mathrm{mmHg}, 750,1000,4000 \mathrm{cps}$ では夫々 $16 \mathrm{mmHg}$

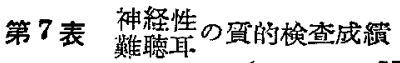
(単位 $\mathrm{mmHg}$ )

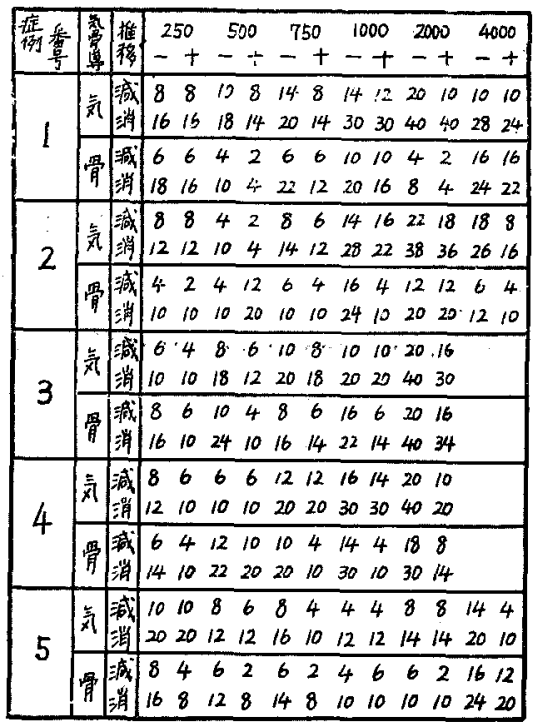

及び $30 \mathrm{mmHg}$, 又 $2000 \mathrm{eps}$ では夫を $20 \mathrm{mmHg}$ 及び $40 \mathrm{mmHg}$ でありた. 即ら少くとも全周波数を通して $20 \mathrm{mmHg}$ までの圧で音の感覚に減弱をきたし, $40 \mathrm{~mm}$ $\mathrm{Hg}$ で音の感覚に消失をきたした。

ii）音の減弱, 消失をきたす陰圧值と陽俚値を比較す ると，陰圧は陽仕より大きな珐領荷によつて音の減弱; 消失をきたした。

iii）ある一つの音の減弱圧値亡消失生值を比㜞する と，前者は後者の大凡半分值であつた・

以上正常耳と神経性難聴耳の䄼查成續を通覧すると， 量的䗝查では圧変動に伴う聴力の低下度，貿的検查では 音の減弱，消失をきたす圧值共に大体同樣の值を示す事 が判明した。

3. 鼓膜愿着症耳について

既往歴に中耳炎文は耳管”炎を経過し，その後難聴を即 え，耳鏡所見で鼓膜の動きが制限されるか，あるい全

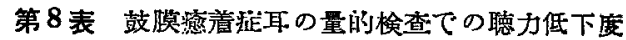
(単位 $d b$ )

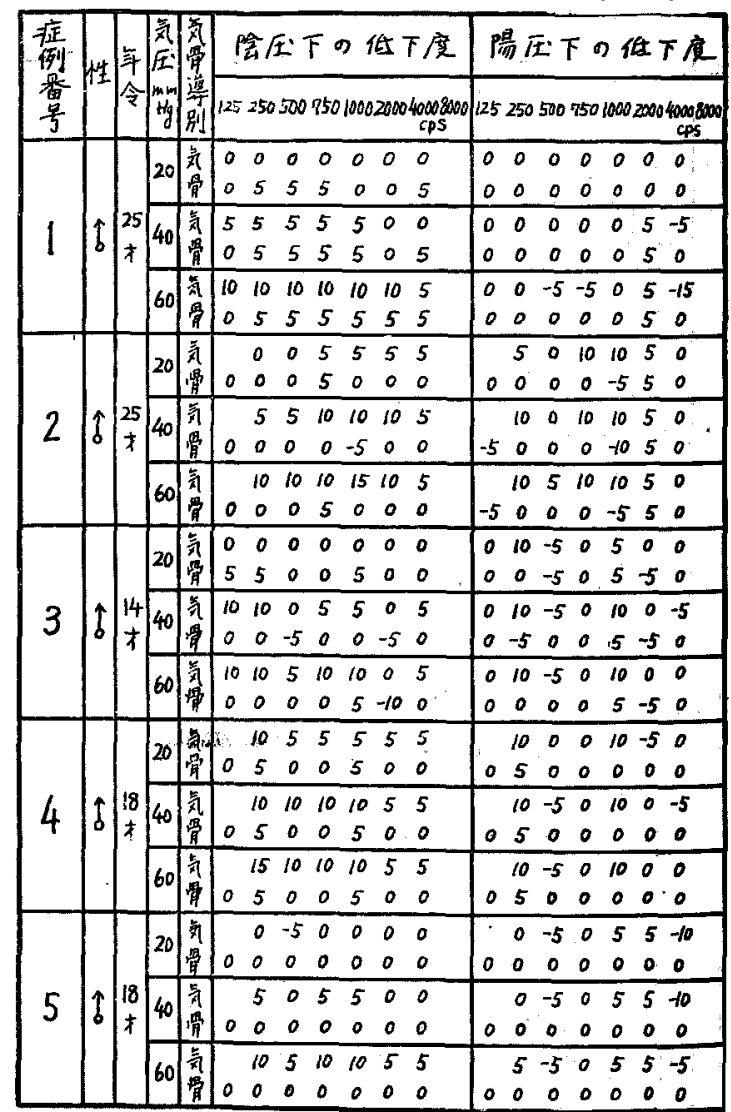


く不勘であるが，耳管通気に際し軽度な狭窄を認めるの

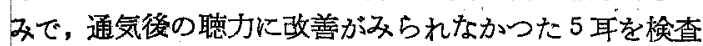
奶象とした。なお症例 2，4は鼓獏成形術を施行した際， 鼓膜の洕着を確認した。

a. 量的裣查

個々の症例の童的㭘查成績から圧変動に伴ら聴力の低 下度を求めた（第8表).

1) 陰生下の気尊

陰圧による聴力の低下度は压の程度によつて異る . 即 ち $-20 \mathrm{~mm} \mathrm{Hg}$ の圧負荷は殆ど 聴力変化を薏起しない が (症例 4 除く)，-40 mmHg で洁 $1000 \mathrm{cps}$ 以下の 周没数域で 5 万至 $10 \mathrm{db}$ の聴力低下をみ， $-60 \mathrm{mmHg}$ では10 万至 $15 \mathrm{db}$ の低下をみた。しかしこれ等の聴力 低下度は正常耳あるいは神経性難聴耳のそれには遠く及 は去なかった。

\section{2）陽圧下゙の気導}

陽庄下の聴力低下度は最大 $10 \mathrm{db}$ であつて，さしたる 著变は認められなかつた・な和 $20 \mathrm{mmHg}$ の圧負荷によ る聴力低下度と $40 \mathrm{mmHg}$ あるいは $60 \mathrm{mmHg}$ の圧負 荷による低下度は大凡等しかつた。更に症例 2 以外の 4 耳では 500cps 及び $4000 \mathrm{cps}$ で僅な聴力上昇をきたし t.

陰圧下の気導聴力の低下度と陽圧下のそれとを比較す ると前者が遥に大であつた。

3）陰王及び陽生下の赑導

陰湯敦れの圧によつても，全周没数で殆んど骨導聴力 北变化は諗められなかつた。これは正常耳あるいは神経 性難聴耳の検查成績とは全く異る所であつた。

附 耳栓骨導差

第9表のような祫查成績をえ た.これによると全症例で耳柽 骨導差は極めて小であつた 0 乃 至 $5 \mathrm{db}$ ).

な打全症例で恩地氏法を計つ た所，250,750cps 其经骨導差 は 0dbであつた。

b. 質的烚查（第 10 表）

1) 気尊

陰王負荷の際は正常耳あるい
第9 表 鼓膜瘾着谞耳の 耳栓肾薄差

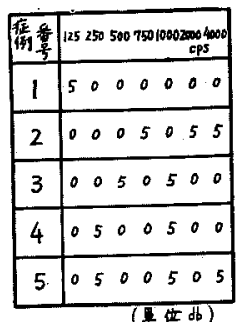
俚神経性難聴耳に比較して大きな陰王值ではあるが，音 の娍弱更には消失をきたした。しかしながら陽圧負荷の 際治んどの症例で音の減㖊住あつても消失はみられな かつた。但し症例 2，3，4の 1000 eps の音は陽圷負荷 て減弱, 消失をみた。

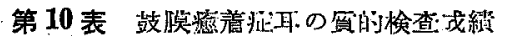

(単位 $\mathrm{mmHg}$ )

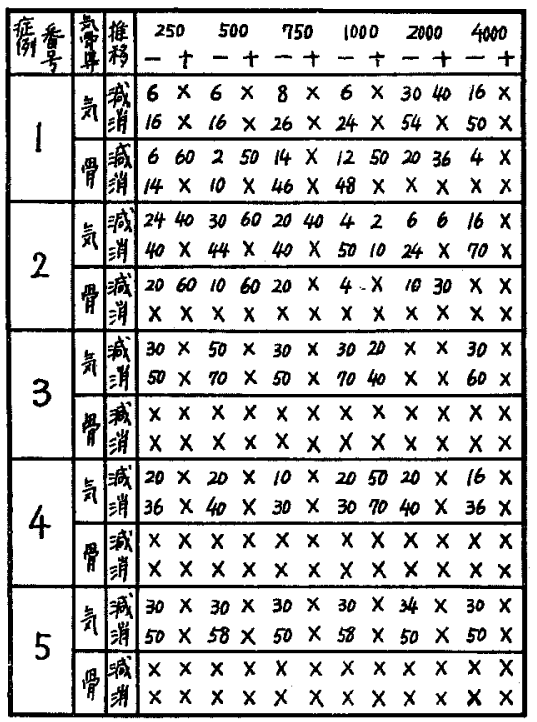

2)骨導

各症例別に述べる之, 症例 $3,4,5$ は陰陽孰れの圧に よつても音の減弱, 消失をみなかつた・症例 2 は压負河 によつてある周波数音が減弱をみ，音の消失は院晹敦れ の圧負荷によつてもみられなかつた・症例 1 は気導聴力 の場合と同椂に陰圧負荷によつて音の減弱, 消失をるた が，陽王負荷では音の消失はみられなかつた。

4. 耳硬北症耳について

既往歴に耳疾患なくして, 耳鳴に始まり，徐々に進行 する難聴を訴え，耳鏡所見並びに耳管通気度に異常な く，鼻・咽頭化むなんら疾患を諗めないが，気導・骨導 聴力検查等から耳硬化症を疑つた 30 耳で本恰査法を行 つたがこつではその中の 10 年の検査成績を記載する ことにした。な扮他つ 20 耳の検查成績はほざこつに記 載された成緢と一致していた＼cjkstart检䍒対象の 10 耳中症例 1，2，3，4，6，8，10の7 耳は内耳開空休を施行したが， その際鐙骨の運陲性を調べ，耳硬化症である事を磪認し ている.

a. 罕: 的険查

個々の症例刀㻎的愉查成績から压变動仁伴う聴力の低 下度を求めた（第11表).

1) 気 導

陰楊㸉れの圧によつても，気導聴力の低下゙度は $10 \mathrm{db}$ 以内の変化を全泟例で示した . 又王变動つ程度と聴力低 
第 11 表 耳硬化趼耳の墨的検查ての聴方低下度

(早位 db)

\begin{tabular}{|c|c|c|c|c|c|c|c|c|c|c|c|c|c|}
\hline \multirow{2}{*}{\multicolumn{2}{|c|}{$\begin{array}{c}\text { 症 } \\
\text { 例 } \\
\text { 番 } \\
\text { 号 }\end{array}$}} & \multirow{2}{*}{ 性年 } & \multirow{2}{*}{ 可氞 } & \multirow{2}{*}{ 骨 } & 㓌压下の低下度 & 低下度 & \multirow{2}{*}{$\begin{array}{l}\text { 症 } \\
\text { 例 } \\
\text { 鬼 } \\
\text { 罗 }\end{array}$} & \multirow{2}{*}{\multicolumn{2}{|c|}{ 性年 }} & \multirow{2}{*}{\multicolumn{2}{|c|}{ 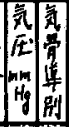 }} & \multirow{2}{*}{\begin{tabular}{|l|l|} 
狯压Fの低下座 \\
1252505007501000200040008000 \\
$C P 5$
\end{tabular}} & \multirow{2}{*}{ 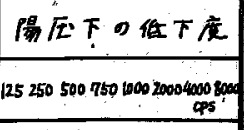 } \\
\hline & & & & & $\begin{array}{c}440008000 \\
\text { CPS }\end{array}$ & $\begin{array}{l}400087500 \\
c 9 s\end{array}$ & & & & & & & \\
\hline \multirow{3}{*}{1} & & & & 骨 & \begin{tabular}{|llllllll}
20 & 10 & 10 & 10 & 5 & -5 & 5 & 0 \\
15 & 15 & 10 & 10 & 0 & 0 & 0 & \\
\end{tabular} & 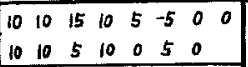 & & & & 20 & & $\begin{array}{|cccccccc|}5 & 5 & 10 & 5 & 5 & 0 & 0 & 0 \\
10 & 10 & 15 & 15 & 5 & 0 & 0 \\
\end{array}$ & $\begin{array}{lllllll}10 & 15 & 15 & 10 & 10 & 5 & 0 \\
15 & 5 & 15 & 10 & 10 & 0 & 0\end{array}$ \\
\hline & & $\sqrt{28}$ & & 霅 & 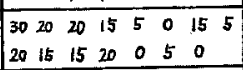 & $\begin{array}{|cccccccc|}25 & 15 & 30 & 15 & 10 & 0 & 5 & 5 \\
20 & 15 & 10 & 15 & 5 & 5 & 0 \\
\end{array}$ & 6 & $\uparrow$ & $2 9 \longdiv { . }$ & 40 & & $\begin{array}{|cccccccc|}20 & 15 & 15 & 10 & 10 & 0 & 5 & 5 \\
15 & 15 & 20 & 20 & 10 & 10 & 5 & \\
\end{array}$ & $\begin{array}{llllllll}15 & 15 & 20 & 15 & 15 & 10 & 0 & 5 \\
20 & 10 & 20 & 15 & 10 & 0 & 0 & \\
\end{array}$ \\
\hline & & & & & \begin{tabular}{|cccccccc}
35 & 30 & 30 & 20 & 10 & 0 & 15 & 5 \\
20 & 20 & 20 & 25 & 5 & 5 & 5 \\
\end{tabular} & $\begin{array}{|cccccccc|}30 & 20 & 30 & 20 & 10 & 0 & 15 & 10 \\
20 & 20 & 15 & 20 & 10 & 5 & 5 & \\
\end{array}$ & & & & 60 & & \begin{tabular}{|llllllll}
20 & 20 & 20 & 15 & 15 & 0 & 5 & 5 \\
20 & 15 & 20 & 20 & 15 & 10 & 5 & \\
\end{tabular} & $\begin{array}{|llllllll|}20 & 20 & 25 & 15 & 15 & 10 & 5 & 5 \\
20 & 15 & 25 & 20 & 15 & 5 & 5 & \\
\end{array}$ \\
\hline \multirow{3}{*}{\multicolumn{2}{|c|}{2}} & & & & \begin{tabular}{|lllllllll}
10 & 10 & 5 & 5 & 5 & 0 & 5 & 0 \\
10 & 10 & 15 & 15 & 10 & 0 & 0 & \\
\end{tabular} & $\begin{array}{|cccccccc|}10 & 5 & 5 & 5 & 5 & 0 & 5 & 5 \\
5 & 15 & 10 & 15 & 15 & 5 & 0 & \\
\end{array}$ & & & & 20 & & $\begin{array}{|llllllll|}5 & 10 & 10 & 5 & 5 & 0 & 5 & 0 \\
5 & 10 & 10 & 5 & 10 & 5 & 5 & \\
\end{array}$ & 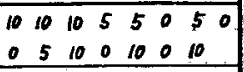 \\
\hline & & $t$ & & & 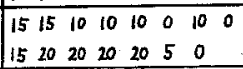 & $\begin{array}{|llllllll|}0 & 15 & 10 & 10 & 10 & 5 & 5 & -5 \\
15 & 20 & 15 & 20 & 15 & 5 & 0 & \\
\end{array}$ & 7 & it & 21) & 40 & & 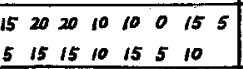 & $\left|\begin{array}{cccccccc}15 & 20 & 15 & 10 & 10 & 5 & 15 & 5 \\
5 & 10 & 15 & 5 & 15 & 0 & 15\end{array}\right|$ \\
\hline & & & 60 & & 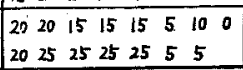 & $\begin{array}{|cccccccc|}15 & 20 & 15 & 15 & 15 & 5 & 10 & 0 \\
20 & 25 & 25 & 25 & 20 & 5 & 5\end{array}$ & & & & 60 & & $\begin{array}{llllllll}20 & 25 & 25 & 15 & 15 & 5 & 15 & 5 \\
10 & 20 & 20 & 16 & 20 & 5 & 15 & \\
\end{array}$ & $\begin{array}{|llllllll|}20 & 25 & 20 & 15 & 15 & 5 & 20 & 5 \\
10 & 15 & 20 & 10 & 20 & 5 & 15 \\
\end{array}$ \\
\hline \multirow{3}{*}{\multicolumn{2}{|c|}{3}} & & & & \begin{tabular}{|cccccccc}
10 & 10 & 5 & 10 & 0 & 0 & 0 & 5 \\
5 & 10 & 10 & 5 & 5 & 5 & 0 & \\
\end{tabular} & 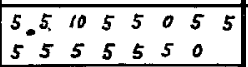 & & & & 20 & & $\begin{array}{|cccccccc|}5 & 10 & 10 & 5 & 5 & 0 & 0 & 0 \\
10 & 15 & 10 & 15 & 10 & 5 & 0 & \\
\end{array}$ & \begin{tabular}{|llllllll}
10 & 10 & 10 & 5 & 10 & 5 & 5 & 5 \\
10 & 15 & 10 & 15 & 10 & 5 & 0
\end{tabular} \\
\hline & & & & 骨 & $\begin{array}{|cccccccc|}20 & 20 & 20 & 20 & 0 & 5 & 5 & 5 \\
10 & 15 & 10 & 10 & 10 & 0 & 0 & \\
\end{array}$ & $\begin{array}{|cccccccc|}10 & 15 & 25 & 10 & 5 & 0 & 10 & 5 \\
10 & 10 & 10 & 10 & 10 & 5 & 0 & \\
\end{array}$ & 8 & $\hat{s}$ & $27 \mid$ & 40 & & $\begin{array}{llllllll}10 & 10 & 15 & 5 & 10 & 0 & 5 & 5 \\
15 & 20 & 15 & 15 & 10 & 5 & 0 & \\
\end{array}$ & $\begin{array}{|llllllll|}10 & 15 & 10 & 5 & 10 & 5 & 10 & 5 \\
15 & 20 & 15 & 20 & 15 & 5 & 0 & \\
\end{array}$ \\
\hline & & & 60 & 裹 & \begin{tabular}{|llllllll}
25 & 25 & 25 & 25 & 5 & 5 & 10 & 5 \\
15 & 20 & 15 & 15 & 15 & 5 & 5 & \\
15 & 15 & 15 &
\end{tabular} & $\begin{array}{|llllllll|}15 & 25 & 25 & 15 & 10 & 5 & 10 & 5 \\
15 & 15 & -15 & 15 & 15 & 5 & 5 & \end{array}$ & & & & 60 & & $\begin{array}{cccccccc}10 & 15 & 20 & 10 & 10 & 0 & 15 & 5 \\
15 & 20 & 15 & 15 & 15 & 5 & 0 & \end{array}$ & $\begin{array}{|llllllll|}15 & 15 & 15 & 10 & 20 & 5 & 10 & 5 \\
15 & 20 & 20 & 20 & 20 & 5 & 0 & \\
15\end{array}$ \\
\hline \multirow{3}{*}{\multicolumn{2}{|c|}{4}} & & 20 & & \begin{tabular}{|cccccccc}
10 & 15 & 15 & 5 & 5 & 0 & 0 & 10 \\
5 & 10 & 10 & 5 & 10 & 5 & 5 & \\
\end{tabular} & $\begin{array}{|cccccccc|}5 & 10 & 5 & 5 & 5 & 5 & 5 & 5 \\
10 & 5 & 5 & 10 & 10 & 0 & 0 \\
\end{array}$ & & & & 20 & & $\begin{array}{|cccccccc|}5 & 10 & 10 & 5 & 5 & 0 & 0 & 0 \\
10 & 15 & 5 & 10 & 5 & -5 & 0 & \\
\end{array}$ & $\begin{array}{lllllllll}10 & 10 & 5 & 5 & 5 & 0 & 5 & 0 \\
5 & 5 & 5 & 0 & 0 & 0 & 0 & \\
\end{array}$ \\
\hline & & & 2 & 育 & $\begin{array}{llllllll}20 & 20 & 20 & 10 & 10 & 5 & 10 & 10 \\
10 & 20 & 15 & 15 & 15 & 5 & 5\end{array}$ & \begin{tabular}{|cccccccc}
10 & 15 & 10 & 10 & 10 & 5 & 10 & 10 \\
15 & 10 & 15 & 15 & 15 & 5 & 0 \\
\end{tabular} & 9 & $\widehat{t}$ & t & 40 & & $\begin{array}{llllllll}20 & 20 & 15 & 10 & 5 & 0 & 5 & 0 \\
10 & 20 & 10 & 10 & 10 & 0 & 5 & \\
\end{array}$ & $\begin{array}{cccccccc}15 & 15 & 10 & 15 & 10 & 10 & 10 & 0 \\
5 & 10 & 10 & 5 & 0 & 0 & 0 & 0 \\
\end{array}$ \\
\hline & & & 60 & 骨 & \begin{tabular}{|llllllll}
20 & 25 & 25 & 15 & 15 & 5 & 10 & 10 \\
15 & 25 & 20 & 20 & 20 & 5 & 5 & \\
\end{tabular} & \begin{tabular}{|cccccccc}
10 & 20 & 20 & 15 & 15 & 5 & 10 & 10 \\
15 & 15 & 20 & 20 & 20 & 5 & 5
\end{tabular} & & & & 60 & & $\left.\begin{array}{llllllll}25 & 25 & 20 & 15 & 10 & 5 & 5 & 5 \\
15 & 25 & 15 & 15 & 15 & 0 & 5 & \end{array}\right]$ & $\begin{array}{cccccccc}20 & 15 & 15 & 15 & 10 & 0 & 10 & 5 \\
10 & 15 & 15 & 10 & 5 & 0 & 5 & \\
15\end{array}$ \\
\hline \multirow{3}{*}{\multicolumn{2}{|c|}{5}} & & 20 & & $\begin{array}{|cccccccc|}5 & 10 & 10 & 5 & 5 & 0 & 0 & 0 \\
20 & 10 & 15 & 15 & 10 & 5 & 5 & \\
\end{array}$ & $\begin{array}{|llllllll|}10 & 20 & 15 & 5 & 10 & 10 & 0 & 0 \\
20 & 10 & 15 & 15 & 10 & 0 & 5 \\
\end{array}$ & & & 20 & & $\begin{array}{llllllll}20 & 10 & 10 & 10 & 0 & 0 & 5 & a \\
10 & 20 & 10 & 10 & 5 & 0 & 0 & \\
\end{array}$ & $\begin{array}{llllllll}15 & 10 & 5 & 5 & 0 & 0 & 10 & 0 \\
15 & 10 & 10 & 5 & 5 & 0 & 0 & \end{array}$ \\
\hline & & & & 骨 & $\begin{array}{llllllll}15 & 20 & 20 & 10 & 10 & 0 & 5 & 5 \\
25 & 15 & 15 & 25 & 20 & 0 & 5 & \\
\end{array}$ & $\begin{array}{llllllll}15 & 25 & 20 & 10 & 15 & 10 & 0 & 0 \\
25 & 15 & 20 & 25 & 15 & 0 & 5 & \\
5\end{array}$ & 10 & & & 40 & & \begin{tabular}{|cccccccc}
25 & 20 & 15 & 15 & 5 & 5 & 10 & 0 \\
15 & 20 & 15 & 10 & 10 & 5 & 5 & \\
\end{tabular} & \begin{tabular}{|cccccccc}
20 & 10 & 10 & 10 & 5 & 5 & 10 & 0 \\
20 & 15 & 10 & 10 & 10 & 0 & 0 & \\
\end{tabular} \\
\hline & & & & & $\begin{array}{llllllll}20 & 30 & 20 & 15 & 10 & 5 & 0 & 5 \\
25 & 20 & 20 & 25 & 20 & 0 & 5 & \\
\end{array}$ & \begin{tabular}{llllllll|}
20 & 30 & 20 & 15 & 15 & 10 & 0 & 0 \\
25 & 20 & 20 & 30 & 20 & 0 & 5 &
\end{tabular} & & & & 60 & & $\begin{array}{llllllll}30 & 25 & 20 & 20 & 5 & 5 & 10 & 5 \\
20 & 25 & 20 & 15 & 10 & 0 & 5 & \end{array}$ & 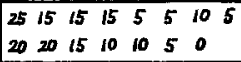 \\
\hline
\end{tabular}

下度の関係は不定であつだ

\section{2）益導}

隍陽敦れの压によつても，全 症例で骨導聴力の低下度は $5 \mathrm{db}$ 以内であらた。

\section{附 耳栓骨䔿差}

第12表のよらな梌查成績を えた・これによると全症例で耳 栓骨尊差は極めて小であつた ( 0 乃至 $\pm 5 \mathrm{db}$ ).

なお全症例で恩地比法を行つ た所，250，750cps 共に敫導差 は Odbであつた。

b. 質的袷查(第 13 萃)

1) 気導

陰陽敦れの生顀荷によつて

も，大体音の減弱，消失をきたすが，2000，4000:psで
は音の減弱，消失をみない症例む多をあつた。しかし音 の減弱及び消失をきたした症例における仕值を正常耳あ。 るいは神経性難聴耳のそれと比較すると非常に太きく， 大多数の症例の各周波数で減弱圧值 $20 \mathrm{mmHg}$ 以上， 消失圧值 $40 \mathrm{~mm} \mathrm{Hg}$ 以上の圧值を示した。
2) 骨
章

除陽孰れの圧負荷によつても，全症例で音の感覚に减 弱、消失をみなかつた。

以上耳硬化症の検㚗成續を通覧すると，軍的検查及び 貿的検查共に正常耳あるいは神経性難聴耳のそれとは全 く異る成績であつた・

c. 㭘查成績と手術咕所見

内耳開空術を施行した 7 耳（症例 $1 ， 2 ， 3 ， 4 ， 6 ， 8 １ 0$ ) の手術時所見と本検查法によつてえた絤查成績を比較検; 討してみた。

手術時行つた鐙骨の可動性検查は次のよらにした，即 ら骨ゾンデを鐙骨の頭部に当てがい，前後及びこれ炸直 


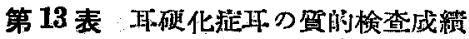
(単位. $\mathrm{mm} \mathrm{Hg}$ )

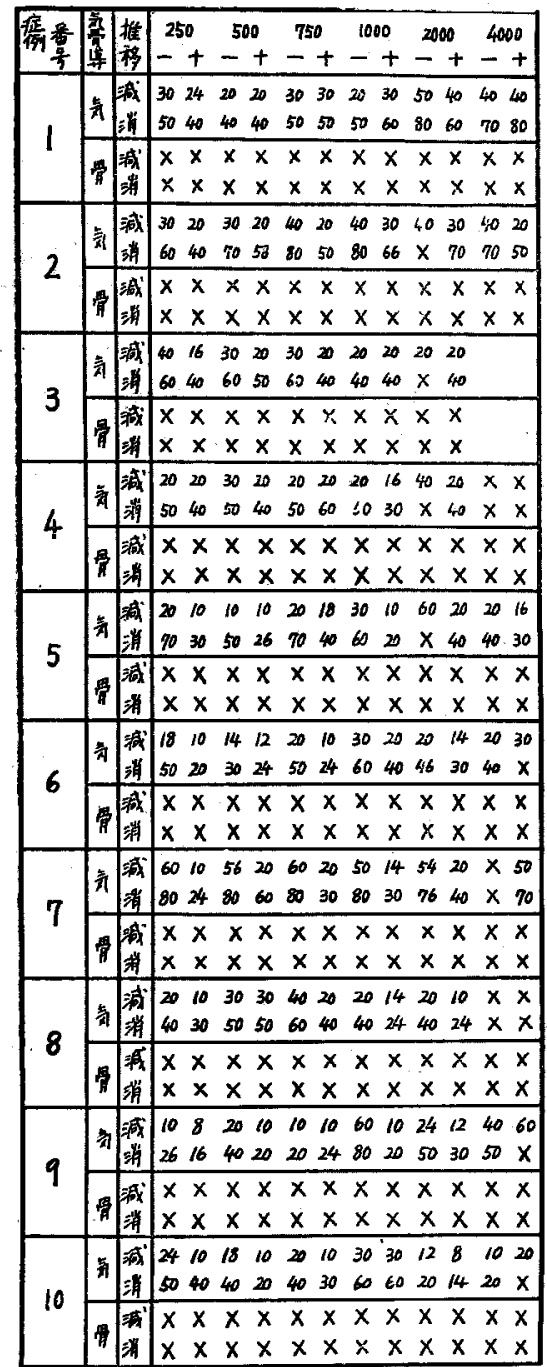

角な方向に動かし，耐運動共に不可能な場合を完全強直 とし，その㛙れかの連動が多少でも可能な場合を不完全 強直とした・これに徉らと7耳中症例 $1 ， 3 ， 6 ， 804$ 耳 性完全强直を呈し，症例 2,4，1003耳は不完全強直で あつた・しかして術前にえた検查成綘（第 11 表，第 13 表）、かは，術前に完全強直の症例を判別することはで さなかつた。

5. 砧鐙関節遊離の 1 症例について

2 才の頃，右側急性乳稼突起炎を起し，直らにシュワ ルチェ氏手術を施行したが，その後 17 才の現在に至る
きで右側難聴を訴え，その聴力改善を希望して来院した

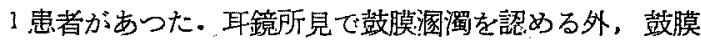
の運動にも異常なく，耳管通気度も正常であつた。しか し骨導聴力は正常であるにも拘らず，気導聴力は会話音 域で平均 $55 \mathrm{db}$ の損失を認めた。更に Weber 氏法は 左扁し，Rinne 氏法 (一)，恩地氏法 (一) と云ら検查 成䋶をえた・そしてこの患者で本検查法を行つた所，単 なる耳硬化症ではなく，耳小監連鎖に何等か他の障碍を もつた症例ではないかとの推測をえたので，一先ず耳内 的に中耳胵を開放し耳小县の妆態を調へたた所，砧鐙関節 の遊睢を確認し，更に鐙骨の不動性を䜅めたので直らに 内耳関空術を施行した．術後 2 週間目頃より聴力改善を 自覚し，術後 3 ケ目の気咅聴力検査では会話音域で平 均 $20 \mathrm{db}$ となり著明な聴力の改善を認めた。この症例に 特いて術前に行つた 本検査の検查成績（第 14 表）を検 討した所，仰か與味ある知見をえたので記述する。

a. 黨的検查:

量的㭘查成續から圧変動に伴う聴力の低下度を求めた （第 14 表 a).

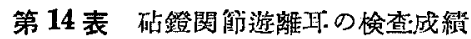
a 量的錸查.

(単位 $d b$ )

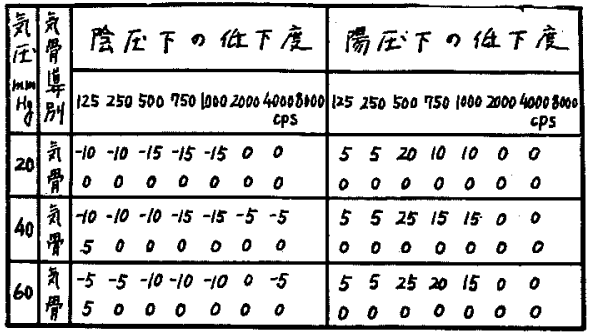

b 留的梌查

(单位 $\mathrm{mmHg}$ )

\begin{tabular}{|c|c|c|c|c|c|c|c|c|c|c|c|c|}
\hline 竞 & \begin{tabular}{|l} 
推 \\
移 \\
\end{tabular} & $\begin{array}{c}250 \\
-+\end{array}$ & & & & & - & 0 & & $\begin{array}{r}2000 \\
+\end{array}$ & & + \\
\hline 7 & $\begin{array}{l}\text { 增 } \\
\text { 淢 } \\
\text { 消 }\end{array}$ & $\begin{array}{l}10 \\
404 \\
\times 12\end{array}$ & $\begin{array}{l}10 \\
30 \\
x\end{array}$ & $\begin{array}{l}8 \\
26\end{array}$ & $\begin{array}{l}10 \\
30 \\
\times\end{array}$ & $\begin{array}{l}10 \\
20\end{array}$ & $\begin{array}{l}6 \\
40 \\
x\end{array}$ & $\begin{array}{l}12 \\
30\end{array}$ & $\begin{array}{l}30 \\
x \\
x\end{array}$ & $\begin{array}{l}10 \\
20\end{array}$ & $\begin{array}{l}30 \\
x \\
x\end{array}$ & x \\
\hline 骨 & 溥 & $\begin{array}{ll}x & x \\
x & x\end{array}$ & $\begin{array}{l}x \\
x\end{array}$ & & $\begin{array}{l}x \\
x\end{array}$ & $x$ & $\begin{array}{l}x \\
x\end{array}$ & $\begin{array}{l}x \\
x\end{array}$ & & $\begin{array}{l}x \\
x\end{array}$ & & $\begin{array}{l}x \\
x\end{array}$ \\
\hline
\end{tabular}

1) 気 遒

陰王下の気遒聴力圷負荷によつて, 全周波数で聴力 上昇をみた。即ち $1000 \mathrm{cps}$ 以下の周波数域では 10 乃至 $15 \mathrm{db}$ の聴力上梨をみ，2000，4000 cps では5 db の上年 をみた。 
陽E下の気導聴力は $1000 \mathrm{cps}$ 以下の周波数域で 聴力低下をみた. 特に $500 \mathrm{cps}$ では $20 \mathrm{mmHg}$ の 压負荷で 20db の低下をみた。しかし 2000，4000 cps では全く聴力変化は認められなかつた。

2) 骨導

陰陽孰れの圧によつても，全周波数で骨導聴力の 変化は認められなかつた。

附 耳柽骨導差

全周波数で全く耳栓冎道差は認められなかつた。

b. 質的検查（第 14 表 b)

1) 気 導

$1000 \mathrm{cps}$ 以下の周波数域では $-10 \mathrm{~mm} \mathrm{Hg}$ までの僅 な陰王負荷によつて先ず気導音は堌大し，更にー30乃 至 $-40 \mathrm{mmHg}$ まで圧を負荷すると音の減弱をみるが， 遂に音の消失はみられなかつた。

陽纴を負荷すると，僅な圧負荷によつて音の減弱, 消 失をみた。但し 4000:ps では音の減弱，消失はみられ なかつた。

\section{2）学 導}

除陽㸉れの压を負荷しても，全周波数で音の感覚の減 弱，消失はみられなかつた。

\section{IV. 検查成績の陰陽性分類}

先づ気導の量的・質的検查成積を詳細に検討すると， 各症例で大なり小なり種る違つた值が出てくるため、こ れをるつて各症例を陰陽性に 2 大別する事潄めて因難 であるが，骨遒の量的・犋的検查成績によれば各症例の 陰陽性分漬が可能である事を知つた。即ち骨導の量的検 查成績について云えば $1000 \mathrm{cps}$ 以下の周波数域で 20 $\mathrm{mmHg}$ の圧負荷により $10 \mathrm{db}$ 以上の聴力低下をきたす 症例（陽性例）と $60 \mathrm{mmHg}$ の圧を負荷しても0乃至 $5 \mathrm{db}$ 程度の聴力低下しかみられない症例（陰性例）と に分類されるし，骨導の質的検查成續について云えば 1000:ps 以下゙の周波数域で圧の変動に伴つて音の感覚に 減弱あるいは消失をみる症例 (陽性例) 之音の感覚に全 く変化をみない症例（陰性例）とに大別される・しかし ながら骨導の量的検查成績による各症例の陰陽性別と質 的検查成績炕よる陰陽性別とを対比してみると，この両 者は全く一致しているので，骨導の量的あるいは質的検 查成績の㛙れかに拠つて各症例の陰陽性を決定しうるわ けである・故に雨後の陰湯性分類を行うに当つては簡単 に测定する事がでさる骨導の質的検查成績のみを採る事. にしたい。

今各症例を险陽性敦れかに 分類し顧ると，第 15 表の

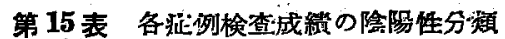

\begin{tabular}{|c|c|c|c|c|c|c|c|c|}
\hline 庄洒名 & 拉倒 & 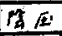 & 稿龺 & $1 \bar{l}^{9} \cdot \bar{x}$ & 梌空 & $\sqrt{2}$ & 余捂 & 是 \\
\hline 症例名 & 数 & 戛垃制 & 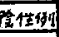 & 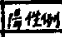 & 原性制 & 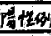 & 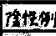 & 列 \\
\hline 正常耳 & 10 & 10 & & 10 & & 10. & & \\
\hline 神脏性踓㬝耳 & 5 & 5 & & 5 & & 5 & & \\
\hline 数膜疮着症白 & 5 & 1 & 4 & & 5 & & 4 & 1 \\
\hline 耳研化症耳 & 10 & & 10 & & 10 & & 10 & \\
\hline 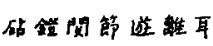 & 1 & 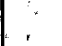 & 1 & & 1 & & 1 & \\
\hline
\end{tabular}

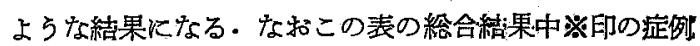
活陰王検查と陽壬検查でその結果が 相違した症例であ る.

\section{V. 総括並びに考按}

従来の Gellé 氏法で用いられた 音源としての音叉の. 振動音け減衰音であるため，可聴間を越す瞬間を捉えに く、，Gellé 氏法のような圧変動に伴う聴力の変化を患 者自身に答えさせる検查法では極めてその答が不正確と なり，高度の難聴者では一層不確実になる. 又圷変動を 徉来の Gellé 氏法のようにボリチェル球で行らと，そ の圧变動速度が大旦不定となり，倹查が粗雑になりが ちである、これ等の久点を補うため音源としてはオージ オメーターを用い，王変動を正確にするためにはマノメ ーターを装備して压変動速度を一定にするよう努めた。

本絤查法 (気導・骨導の量的・質的検査を総称寸. 以 下同様）の骨導検查成績によつて各症例を陽性あるい恃 陰性に方類すると第 15 表のようになるが，陰性を示し た耳硬化症耳，砧鐙関節遊離耳（この症例は蹬骨强直を 合併していた）及び鼓膜瘾着症耳の大部分恃この表の症

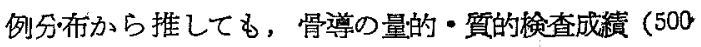
cps を中心とした $1000 \mathrm{cps}$ 以下の周波数域で 圧变動に 伴う聴力低下江殆九ど認め難い）からみても，耳小骨連 鎖の障碍が存在するため，か〉る結果をえたるのと推察 される・これは従来の Gellé 陰性と決定された症例沉 鐙骨強值の 䛦断が:下された事と大凡符合する事実であ る.

な叔骨導㭘查を行られ当り耳孔部に圧変動用の有孔耳 烃を使用したつめ，陽性を示した正常耳文び神経性難聴: 耳では，耳柽を使用しない場合より良く聴え（本論文 ではこれを仮に耳棱胥導差と称した)，陰性を示したる 筷患耳では殆んど媤えは不変であつた。これは恩地氏法 の理論と全く軌を一にするすのである・しかしながら私 が観察した上記の耳栓骨尊差甶地氏法の骨尊美に比㜞 
すると多少小さな值をえた・これは私が用いた有孔耳烃 には約 $4 \mathrm{~mm}$ の孔があり，耳孔部の開鎖が 不完全なた めであろらと思われる。

投て皆同一に陰性を示した耳硬化症耳, 鼓膜癒着症耳 及び砧鐙関節遊離耳等を鑑別する目的のために，これ等 諸疾患を気導の質的検查成績で比較检討した所，次に述 ベるような與味ある結果をえた。

1) 耳硬化症耳：1000 cps 以下の周波数域では，陰陽 敦れの王負荷によつても，大体気尊検查音汇減弱，消失 をきたした。しかし音の減弱圧值及び消失王值を正常耳 あるい性神経性難聴耳のそれと比較すると非常に大き く, 大多数の症例の各周波数で減弱圧值 $20 \mathrm{~mm} \mathrm{Hg}$ 以 上, 消失圧值 $40 \mathrm{mmHg}$ 以上の圧值を示した。

2）鼓膜签着症耳：陰圧を顀荷すると，耳硬化症耳で みられると同様に，気導検查音の減弱，消失をみるが， 陽壬負荷の際治んどの症例で検查音の消失はみられな かつた.

3）砧鐙関節遊離耳：陽圧を負荷すると，耳硬化症耳 でみられると同椂に，気薯検查音の減弱，消失をみる が，陰殴を負荷すると $-10 \mathrm{~mm} \mathrm{Hg}$ と云ら僅な代で先 つ㭘查音は堌大し，更に -30 乃至 $-40 \mathrm{mmHg}$ まで任 を負荷して行く之検查音の減弱をみた，な打僅な陰圧負 荷により検查音の增大をみたのは，耳内筋並びに鼓膜の 熙張何人らかの変化济され，その結果惹起されたも のであるらか.

即ち以上の険查成績を通覽すると，これまで一律に陰 性を示していたこれ等 3 疾患の鑑別もある程度可能であ るように思われる。

次に本検查法を行うに当り最も有効であつた周波数に ついて述べたいと思う. 正常耳及び 神経性難聴耳の気 導・骨尊の量的検查成樍 (第 2 表及び第 5 表) をみると, $1000 \mathrm{cps}$ 以下の周波数域の気導不び骨導聴力の王变動に 伴ら低下度は $2000 \mathrm{cps}$ 以上の周没数域の 低下度上り著 明であつた（特に $500 \mathrm{cps}$ では著明な聴力低下度をみ た). 即ら正常耳及び神経性難聴耳に压変動が起きると， 今まで正常な機能を営んでいた鼓膜や耳小骨連鎖が音響 の伝音に障碍をきたして，殊に鼓䐺や耳小骨連鎖機能と

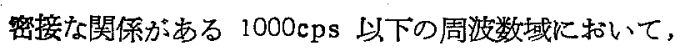
著明な聴力低下をみたものと考えられる. 又正常耳及び 神経性難聴耳の気導・骨導の質的検查成結（第 4 表及び 第 7 表)をみると，1000 ps 以下の周波数域の気尊及び 骨導検查音は 2000 及び $4000 \mathrm{cps}$ の検查音で検查した場 合より跬な压を負荷して，その音覚に減弱あるいは消失
ををたすと云う成績をえた．即ち $1000 \mathrm{cps}$ 以下の周波 数は圧变動に対して 2000 及び $4000 \mathrm{cps}$ より銧敏である ことがわかる. 以上の結果加ら 500cps を中心とした $1000 \mathrm{cps}$ 以下の周波数が本検查を行うに当り最も有效な 周波数であると推察される.この事については文献的に る低調音は高調音より王変動により影響を受汁易いと明 記されているが (Mach and Kessel, Békésy, Rasmussen etc.)，上記の点からも首肯される。

次に圧の問題について少し触れてみる. 正常耳及び神 経性難德耳の気導・骨導の量的検查成續（第 2 表及び第 5 表) で圧負荷による聴力低下度を観察すると, 自0至 $20 \mathrm{~mm} \mathrm{Hg}$, 自 20 至 $40 \mathrm{~mm} \mathrm{Hg}$, 自 40 至 $60 \mathrm{mmHg}$ の順 に聴力の低下度は次第に減少する.特に自 40 至 $60 \mathrm{~mm}$ $\mathrm{Hg}$ の圧による低下度は前2者に比べ概して小さいので， 本検査を行うには 20 及び $40 \mathrm{mmHg}$ の圧負倚を試みる たけで充分と思われる・次に気導・骨導の質的検查では 最高 $\pm 80 \mathrm{mmHg}$ までの圧変動を試みたが，正常耳及び 神経性鹳聴耳の最高減弱圧值 及び最高学失圧值は夫ぬ $20 \mathrm{mmHg}$ 及び $40 \mathrm{mmHg}$ である事からも察せられる ように，40 m m Hg までの圧変動で質的検查は充分遂行 できと思ら。

双て臨床的に本㭘査法を用いてみると，その検查方法 はあまりに繁雑過ぎるので，検查順序をより合理的に し、不必要と思われる周波数や圧による検查を除いて， 必要にして充奇なな周波数あるいは圧で険查を行い，しか も本㭘查法と同様の診断的価值をるつ新しい形式の検查 法を考案したので、これについて簡単に述べてみる（新 Gellé 氏法と仮称す). 即ち次の a) b) c) の順に検查 する。

a) 気尊・管導闘值の測定

b) 500eps の骨導検查音 (闒值上 $5 \mathrm{db}$ の音) で質 的㭘查施行：Gellé 陽性あるいは陰性の泆定.

c) 陰性例は $500 \mathrm{eps}$ の気尊検查音（䦪值上 $5 \mathrm{db} の$ 音）で質的検查施行：耳硬化症, 鼓膜痖着症あるいは 砧鐙関節遊離疾患の鑑別決定.

なお c) 検查を行つた場合の上記 3 疾患の特徽につい ては前に列記したのでこっでは省略する。

この新 Gellé 氏法については今後な拈多数の症例に 当つてみて，不備な点があれば補正し，より正確な椧查 法にしたいと思う次第である。

\section{VI. 結 語}

従来の Gellé 氏法を改良し，外耳道に陽圧及び陰圧 を負荷した際の気尊・骨導の量的・質的検查（上下本椧 
查と略称す）を行つた。

研究の対象としては，鼓膜欠損を伴わないで正常な耳 管通気度をむつ中耳伝音系疾患耳，正常耳並びに神経性 難聴耳を選び，次のような知見をえた。

1）本検查法の骨尊の質的検查成績に拠れば，正常耳 並びに神経性難聴耳は陽性を示し，耳硬化症耳及び砧鐙 関節遊離耳（鐙骨強直を合併）は陰性を示した。な䄈 脱癒着症耳では大多数の症例が陰性を示した。

2）本検查法で陰性を示した耳硬化症，鼓募癒着症及 び砧鐙関節遊離疾患の監別は気導の質的検查によりある 程度できる可能性がある・次にこれ等 3 疾患の気尊の質 的検查成績を簡単に列記すると。

i）耳硬化症：外耳道に 陰陽敦れの压を負荷してる 気尊㭘查音は大体減弱した。

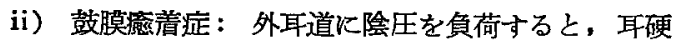
化症でみられると同様に，気導検查音の減弱をみるが， 陽圧負荷の際は検查音の減氜をみなかつた。

iii）砧鐙関節 遊離疾患：外耳道に陽圧を負荷する と，耳硬化症でみられると同様に，気尊検查音の減鸟哥を みるが，陰圧負荷の際は僅な珐によつて先つ検查音は増 大し，更に圧を負荷すると検查音の減弱をみた。

3）本検查法によつて子小取硬化症と診断された症例 に内耳開空術を施行する際，先づ鐙骨の可動性を調へた 所，その症例の総てに鐙骨の強直を認めた．しかし強直 の程度を術前に本検查法で泆定する事はできなかつた。

4）本検查に用いられる最す有效な周波数は $1000 \mathrm{cps}$ 以下の周波数域殊に $500 \mathrm{cps}$ を中心とした周波数であ る.

5）本検查法と同様の診断的俩值をもち，而も臨床的 飞簡単に使用できる検查法を新しく提案し，これを新 Gellé 氏法と仮称した，その方法法次の如く。

a) 気尊・骨導閾暄の湘定.

b） $500 \mathrm{cps}$ の骨首検查音 (䦪值上 $5 \mathrm{db}$ の音) で質 的㭘查施行：Gellé 陽性あるいは陰性の決定.

c) 陰性例性 $500 \mathrm{cps}$ の気導検查音（閾值上 $5 \mathrm{db} の$ 音）で質的検査施行：耳硬化症，鼓膜痖着症あるいは 砧鐙関節遊離疾患の鑑別決定.

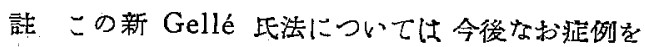
加えて，その的確性に関し研究を進的たい。

\section{参 考 文 献}

1) Békésy: Phys. Zeitschr., 30, 1929. sy: Ann. d. Phys., 13, 1932.

Zeitschr. Ohrenheilk.. 18, 1888.

3) Bezold:

4) Bing:

Mschr. Ohrenheilk., 33, 1899. 5) Bloch: Zeitschr. Ohrenheilk., 25, 1894. 6) Brühl: Zeitschr. Ohrenheilk., 32, $1898 . \quad$ 7) Dishoeck: Arch. f. O., 144, 1938. 8) Gell': Transaet. of the internat. med. congr., 1881, London. 9) Hallpike: J.O.L.. 45, 1930. 10) 広瀬：日本耳悬咽喉科会報, 55, 1952. 11) Jone and Edmonds: Ann. of

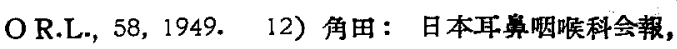

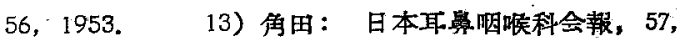
1954. 14) Kelly: J. Exp. Phy., 21, 1937. 15) Kietz u. Zangemeister: Zeitschr. f.L.R.O., 32, 1953. 16）切替：医学々生物学， 31，1954。17）切替：

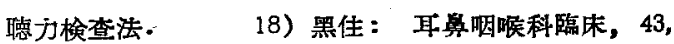
1950. 19）黑佳：日本耳悬咽䐅科会報，53，1950。 20) Lucae: Centralbl. f. d. med. Wissenschaft, 40 u. 41, 1863. 21) Mach and Kessel: Sitzungsber. d. Wiener. 22) 松下：日本耳尊咽喉科会報， 60,1957 . 23) 內藤。他：耳㫷鸣喉科臨床，41，1948. 24）內藤，他：日本耳㐞咽喉科会報，52，1949，25） 內藤, 他：日本耳算咽喉科会報，56,1953. 26) 恩 地：日本耳惑咽知科会報， $54,1951.27 ＼mathrm{~ 恩 地 ： ~}$

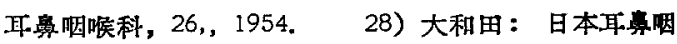
晚科会竍，55，1952. 29） Politzer: Wiener. med. Wschr., 13 u. 14, $1862 . \quad 30)$ Rasmussen: Acta O.L., 34，1946. 31）鈴柰，他：耳悬咽唤科，25, 1953. 32) Thullen: Archiv. f. O.N.K., 164, 1954. 33) Zöllner: Audiologie, $1954 . \quad$ 34) Zöllner u. Thnllen: Zeitschr. f. L.R.O., 30, 1951.

稿を終るに臨み終始御想第な御指導並びに御 校閏を睗わつた恩師高原滋夫教授に深甚な謝意 を表し，併せて有益な御助言を頂いた水河忠敬 搏士に或心より感誎致します。

本論交の婯旨は日本耳悬咽喉科学会中国地方 会第76 例会並びに第77 洌会において器埊され ている.

（原稿到着=昭和 33.10.7日） 